\title{
Activities of daily living in patients with chronic obstructive pulmonary disease with depressive symptoms
}

\author{
Atividades de vida diária em pacientes com doença pulmonar obstrutiva crônica com \\ sintomas depressivos \\ Actividades de la vida diaria en pacientes con enfermedad pulmonar obstructiva crónica y \\ sintomas depresivos
}

Rilda Carla Alves de Souza', Fabíola Cássia de Oliveira Silva Vieira², Graziella Monicky Oliveira Costa³, Kamila Roberta Perpétua de Souza ${ }^{4}$, Laura Maria Gomes de Siqueira ${ }^{5}$, Patrícia Érika de Melo Marinho ${ }^{6}$

\begin{abstract}
I This cross-sectional study assessed the activities of daily living ( $A D L$ ) and risk factors for developing depressive symptoms in patients with chronic obstructive pulmonary disease (COPD) and was carried out at the pulmonology outpatient clinic of the Hospital Universitário Oswaldo Cruz. Two hundred two (202) patients with COPD participated in the study. We evaluated the sociodemographic and anthropometric data, the ADL by means of Pulmonary Functional Status and Dyspnea Questionnaire - Modified version (PFSDQ-M), and the presence of depressive symptoms using the Beck Depression Inventory (BDI). All domains (dyspnea, fatigue and activity changes) of PFSDQ are compromised in patients with depressive symptoms. The prevalence of depressive symptoms was 38.6\%. The chance of developing these symptoms was higher for those who used more than one bronchodilator (OR: 2.82, Cl 95\%: 1.47-5.38, p=0.002), presented dyslipidemias (OR: 2.74, C195\%: 1.24-6.07, $\mathrm{p}=0.012$ ), had a heart disease (OR: 2.82, Cl 95\%: 1.18-6.74, $\mathrm{p}=0.020$ ), presented expectoration (OR: 2.44, CI 95\%: 1.2-4.95, $p=0.014$ ) or did not have a partner (OR: 2.58, CI 95\%: 1.36-4.9, p=0.004).
\end{abstract}

COPD patients with depressive symptoms had all domains of ADL compromised compared to patients without these symptoms.

Keywords | Pulmonary Disease, Chronic Obstructive; Dyspnea; Depression; Efficiency.

RESUMO I O objetivo foi avaliar as atividades de vida diária (AVD) e fatores de risco para o desenvolvimento de sintomas depressivos nos pacientes com doença pulmonar obstrutiva crônica (DPOC). Estudo transversal realizado no ambulatório de Pneumologia do Hospital Universitário Oswaldo Cruz. Participaram do estudo 202 pacientes com DPOC. Foram avaliados os dados sociodemográficos e antropométricos; as AVD, através do Pulmonary Functional Status and Dyspnea Questionnaire - Modified version (PFSDQ-M); e a presença de sintomas depressivos por meio do inventário de depressão de Beck. Todos os domínios (dispneia, fadiga e mudanças de atividades) do PFSDQ-M se apresentaram comprometidos nos pacientes com sintomas depressivos. A prevalência de sintomas depressivos foi de 38,6\%. As chances de desenvolvimento desses sintomas ocorreram para aqueles que utilizavam mais de um broncodilatador

Work developed at the Hospital Universitário Oswaldo Cruz, Recife (PE), Brazil.

'Universidade Federal de Pernambuco (UFPE) - Recife (PE), Brazil. E-mail: rilda.carla@hotmail.com. Orcid: 0000-0002-7610-5891

2Universidade Federal de Pernambuco (UFPE) - Recife (PE), Brazil. E-mail: fabiolacassia@yahoo.com.br. Orcid: 0000-0002-7782-6973

3 Universidade Federal de Pernambuco (UFPE) - Recife (PE), Brazil. E-mail: graziella.monicky94@gmail.com. Orcid:

0000-0002-9292-4926

${ }^{4}$ Faculdade dos Guararapes (UNIFG) - Jaboatão dos Guararapes (PE), Brazil. E-mail: kamila_roberta@hotmail.com. Orcid: 0000-0001-8350-5319

${ }_{5}^{5}$ Faculdade dos Guararapes (UNIFG) - Jaboatão dos Guararapes (PE), Brazil. E-mail: laurasiqueiras@hotmail.com. Orcid: 0000-0003-2446-8743

6Universidade Federal de Pernambuco (UFPE) - Recife (PE), Brazil. E-mail: patmarinho@yahoo.com.br. Orcid: 0000-0002-3093-7481 
(OR: 2,82, IC ${ }_{95 \%}: 1,47-5,38, p=0,002$ ), que apresentavam dislipidemias (OR: 2,74, IC $\mathrm{C}_{95 \%}: 1,24-6,07, \mathrm{p}=0,012$ ), que possuíam cardiopatia (OR: 2,82, IC ${ }_{95 \%}:$ 1,18-6,74, p=0,02); que apresentavam expectoração (OR: 2,44, IC $95 \%$ : 1,2-4,95, p=0,014); e não tinham companheiros (OR: 2,58, IC $\left.\mathrm{C}_{95 \%}: 1,36-4,9, \mathrm{p}=0,004\right)$. Pacientes com DPOC com sintomas depressivos apresentaram todos os domínios das AVD comprometidos em relação aos pacientes sem esses sintomas. Descritores | Doença Pulmonar Obstrutiva Crônica; Dispneia; Depressão; Eficiência.

RESUMEN | El objetivo fue evaluar las actividades de la vida diaria (AVD) y los factores de riesgo para el desarrollo de síntomas depresivos en pacientes con enfermedad pulmonar obstructiva crónica (EPOC). Estudio transversal realizado en el ambulatorio de Neumología del Hospital Universitario Oswaldo Cruz. En el estudio, participaron 202 pacientes con EPOC. Se evaluaron los datos sociodemográficos y antropométricos, las AVD por medio de Pulmonary Functional Status and Dyspnea Questionnaire: Modified version (PFSDQ-M), y la presencia de síntomas depresivos por medio del Inventario de depresión de Beck. Todos los dominios (disnea, fatiga y cambios en las actividades) del PFSDQ-M estuvieron comprometidos en pacientes con síntomas depresivos. La prevalencia de síntomas depresivos fue del 38,6\%. Las posibilidades para el desarrollo de estos síntomas ocurrieron para aquellos que utilizaban más de un broncodilatador (OR: 2,82, IC ${ }_{95 \%}: 1,47-5,38, p=0,002$ ), que tenían dislipidemias (OR: 2,74, IC ${ }_{95 \%}: 1,24-6,07, p=0,012$ ), que tenían enfermedad cardiaca (OR: 2,82, IC ${ }_{95 \%}: 1,18-6,74, p=0,02$ ), que tenían expectoración (OR: 2,44, IC $95 \%$ : 1,2-4,95, p=0,014), y no tenían parejas (OR: 2,58, $\left.I_{95 \%}: 1,36-4,9, p=0,004\right)$. Los pacientes con EPOC y síntomas depresivos tuvieron todos los dominios de las AVD afectados en comparación con los pacientes sin estos síntomas.

Palabras clave | Enfermedad Pulmonar Obstructiva Crónica; Disnea; Depresión; Eficiencia.

\section{INTRODUCTION}

Chronic obstructive pulmonary disease (COPD) associated with depression leads to a poor prognosis for patients and a consequent decrease in quality of life ${ }^{1,2}$. Although depressive symptoms are relatively prevalent in these patients, they are not easily diagnosed by health professionals, since they are subthreshold $3-5$.

Depressive symptoms are associated with mortality ${ }^{6,7}$, disease exacerbation, dyspnea ${ }^{8}$, decreased physical performance, inactivity ${ }^{9}$ and functional limitations in activities of daily living (ADL) $)^{10-13}$. Functional limitation is experienced through progressive loss of physical conditioning, with decreased ability to carry out ADL and reduced muscle strength due to systemic manifestations of disease which may become more severe if associated with depressive symptoms $\mathrm{s}^{14-16}$.

Considering that $\mathrm{ADL}$ may be involved in $\mathrm{COPD}$, it is necessary to know how these activities are manifested in patients with depressive symptoms and which factors could be increasing the chances for developing these symptoms.

Thus, this study assessed the activities of daily living (ADL) and risk factors for developing depressive symptoms in patients with chronic obstructive pulmonary disease (COPD).

\section{METHODOLOGY}

This cross-sectional study involved patients with functional clinical diagnosis of COPD recruited from the Pneumology outpatient clinic of the Hospital Universitário Oswaldo Cruz between March and September 2015. This study was approved by the Ethics Committee for Institutional Research and is in accordance with the Declaration of Helsinki.

Considering the approximate number of 640 patients with COPD in the ambulatory of Hospital Universitário Oswaldo Cruz and the prevalence of depressive symptoms of $28.57 \%$ obtained in the study by Carvalho et al. ${ }^{17}$, the total sample included 194 patients obtained by convenience sampling. Sample size calculation was carried out with an alpha of 0.05 and a $95 \%$ confidence interval.

The study included patients with clinical and functional COPD diagnosis according to the Global Initiative for Chronic Obstructive Lung Disease ${ }^{14}$, and aged over 40 years old. We excluded patients with COPD who presented cognitive, auditory and visual changes which would make it impossible for them to respond to the implemented questionnaires, patients diagnosed with depression, and patients with other lung diseases.

Eligible patients had their anthropometry data (weight and height) and spirometry forced expiratory volume in one second $\left(\mathrm{FEV}_{1}\right)$ forced vital capacity $(\mathrm{FVC})$ and ratio 
$\left.\mathrm{FEV}_{1} / \mathrm{FVC}\right]$ collected directly from the patient's medical record during medical consultation (last spirometry). All the data were performed in the Pneumology outpatient clinic itself. The spirometric data will presented by GOLD classification ${ }^{14}$.

\section{ADL assessment}

We used the Pulmonary Functional Status and Dyspnea Questionnaire-Modified version (PFSDQ-M) for assessing limitations in activities of daily living. It consists of three domains: dyspnea, fatigue during $\mathrm{ADL}$ and changes in $\mathrm{ADL}$ compared to the period before the disease ${ }^{18}$. A partial score was computed ranging from 0 to 100 for each of the three domains, and a total score was formed by summing the partial scores of the three domains for a total value ranging from 0 to 300 . Higher values on the scale indicate greater limitations in $\mathrm{ADL}^{18}$.

\section{Assessment of depressive symptoms}

The Beck Depression Inventory (BDI) was used to evaluate the presence of depressive symptoms. It consists of 21 sets of statements about depressive symptoms in the last 15 days, which are classified in ordinal scale from 0 to 3 , producing total scores ranging from 0 to 63 . Severity levels are identified from 0-13 (no depression), 14-19 (mild depression), 20-28 (moderate depression) and 29-63 (severe depression $)^{19,20}$. We adopted a cut-off point from 0 to 13 (without symptoms) and 14 to 63 (with symptoms) for the purposes of classifying the presence/absence of depressive symptoms for this study.

\section{STATISTICAL ANALYSIS}

We initially conducted distribution of normality and variance homogeneity using the Kolmogorov-Smirnov and Levene tests, respectively. Numerical variables are presented by central tendency and dispersion measurements, and absolute and relative frequencies. Pearson's Chi-Squared or Fisher's Exact tests were used to assess the association between the categorical variables. A comparison between groups with and without depressive symptoms was conducted through the Student's t-test for independent samples or the Mann-Whitney test.

Logistic regression was performed considering the presence of depressive symptoms (yes/no) as the dependent variable. Bivariate analysis was used for the association between the dependent variable and the sociodemographic data, spirometry, kind of medication used and the presence of comorbidities, and the variables with $p \leq 0.20$ in the bivariate analysis were then included in the logistic regression model. Regression analysis was performed by the Backward Lr method. The analysis was conducted using SPSS version 13.0 (SPSS Inc., Chicago, IL) considering a p-value $<0.05$ as significant. A $95 \%$ confidence interval with an error margin of $5 \%$ was applied for all tests.

\section{RESULTS}

Two hundred seventy-nine (279) patients were recruited for the study, but 77 were excluded for not meeting the inclusion criteria, rendering 202 participants. Patients with depressive symptoms had increased chance of dyslipidemia $(62.8 \%, 27$ patients, $\mathrm{p}<0.001)$, diabetes $(61.5 \%, 16$ patients, $\mathrm{p}=0.012)$ and heart disease $(62.5 \%, 20$ patients, $\mathrm{p}=0.003)$ than individuals without these symptoms. Prevalence of depressive symptoms was identified in 79 (38.6\%) of the patients studied. The characteristics of individuals with and without depressive symptoms are shown in Table 1.

Table 1. Characterization of individuals with COPD with and without depressive symptoms

\begin{tabular}{|c|c|c|c|c|c|}
\hline \multirow[t]{2}{*}{ Variables } & $\begin{array}{c}\text { With Symptoms } \\
(n=79)\end{array}$ & \multirow[t]{2}{*}{$\mathrm{Cl} 95 \%$} & $\begin{array}{l}\text { Without Symptoms } \\
(n=123)\end{array}$ & \multirow[t]{2}{*}{$\mathrm{Cl} 95 \%$} & \multirow[t]{2}{*}{ p-value } \\
\hline & n (\%) & & $n(\%)$ & & \\
\hline \multicolumn{6}{|l|}{ Gender } \\
\hline Female & $44(42.7)$ & & $59(57.3)$ & & 0.284 \\
\hline \multicolumn{6}{|l|}{ GOLD Rating } \\
\hline GOLD $2\left(80 \%<F E V_{1} \geq 50 \%\right)$ & $21(31.8)$ & & $45(68.2)$ & & 0.048 \\
\hline GOLD $3\left(50 \%<F E V_{1} \geq 30 \%\right)$ & $42(38.5)$ & & $67(61.5)$ & & \\
\hline GOLD $4\left(F E V_{1}<30 \%\right)$ & $16(59.3)$ & & $11(40.7)$ & & \\
\hline
\end{tabular}


Table 1. Characterization of individuals with COPD with and without depressive symptoms

\begin{tabular}{|c|c|c|c|c|c|}
\hline \multirow[t]{2}{*}{ Variables } & $\begin{array}{l}\text { With Symptoms } \\
(\mathrm{n}=79)\end{array}$ & \multirow[t]{2}{*}{ Cl 95\% } & $\begin{array}{l}\text { Without Symptoms } \\
(n=123)\end{array}$ & \multirow[t]{2}{*}{ Cl 95\% } & \multirow[t]{2}{*}{$p$-value } \\
\hline & n (\%) & & n (\%) & & \\
\hline Age & $64.44 \pm 10.71$ & $(62.04-66.84)$ & $66.81 \pm 9.77$ & $(65.07-68.56)$ & 0.107 \\
\hline Weight & $68.82 \pm 2.36$ & (64.10-73.53) & $66.19 \pm 1.2$ & $(63.8-68.57)$ & 0.279 \\
\hline Height & $1.58 \pm 0.01$ & $(1.56-1.61)$ & $1.6 \pm 0$ & $(1.58-1.62)$ & 0.330 \\
\hline BMI & $27.02 \pm 6.66$ & $(25.53-28.52)$ & $25.81 \pm 4.96$ & $(24.93-26.70)$ & 0.142 \\
\hline \multicolumn{6}{|l|}{ Smoke } \\
\hline Years of smoking & $21.51 \pm 14.27$ & $(18.31-24.7)$ & $19.88 \pm 12.46$ & $(17.65-22.11)$ & 0.394 \\
\hline Packs per year & $24.60 \pm 2.62$ & $(19.37-29.84)$ & $22.72 \pm 1.94$ & (18.87-26.56) & 0.558 \\
\hline
\end{tabular}

GOLD: Global Initiative for Chronic Obstructive Lung Disease; Cl: confidence interval; FEV; forced expiratory volume in the first minute; BMI: body mass index. Chi-Squared Test and Student's t-test, $p<0.05$.

Changes in the assessment of activities of daily living fatigue and activity changes), which were compromised in have been identified in all areas of PFSDQ-M (dyspnea, patients with depressive symptoms (Figures 1,2 and 3).

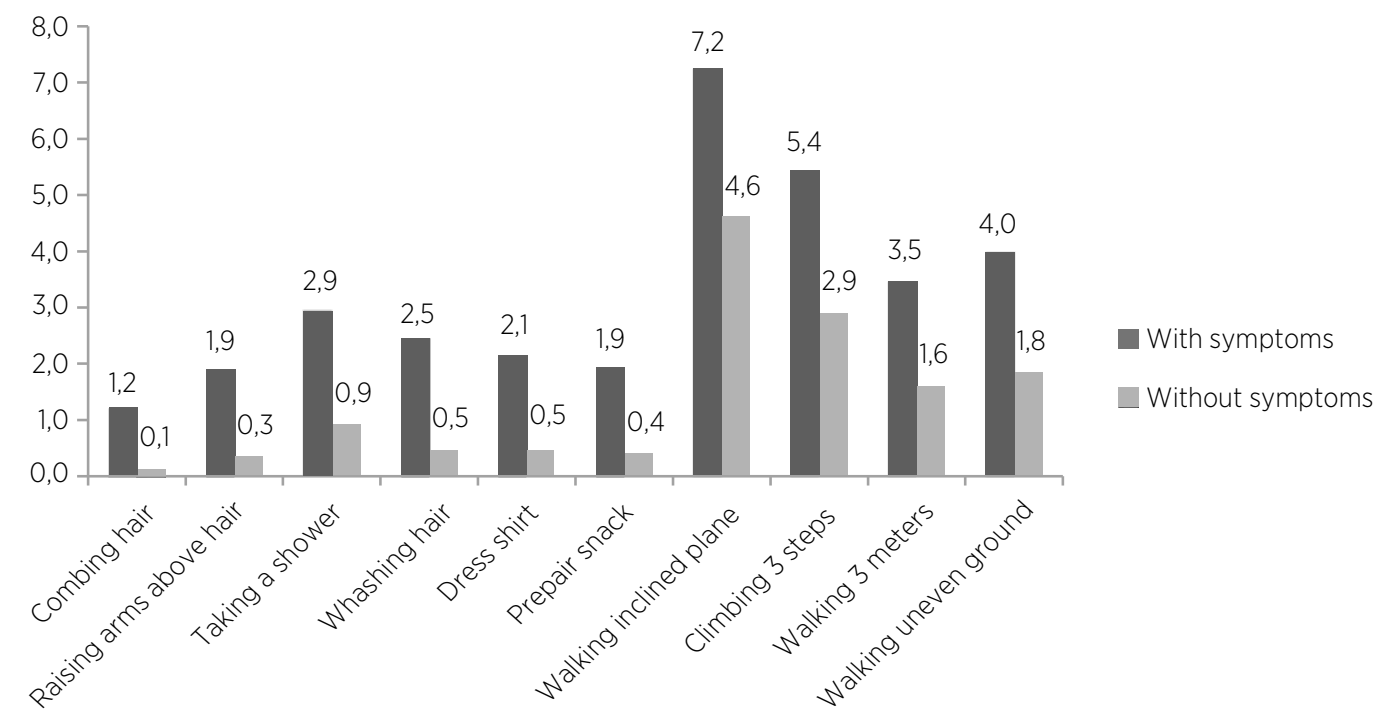

Figure 1. Limitations in activities of daily living imposed by dyspnea according to the PSFDQ in the presence and absence of depressive symptoms

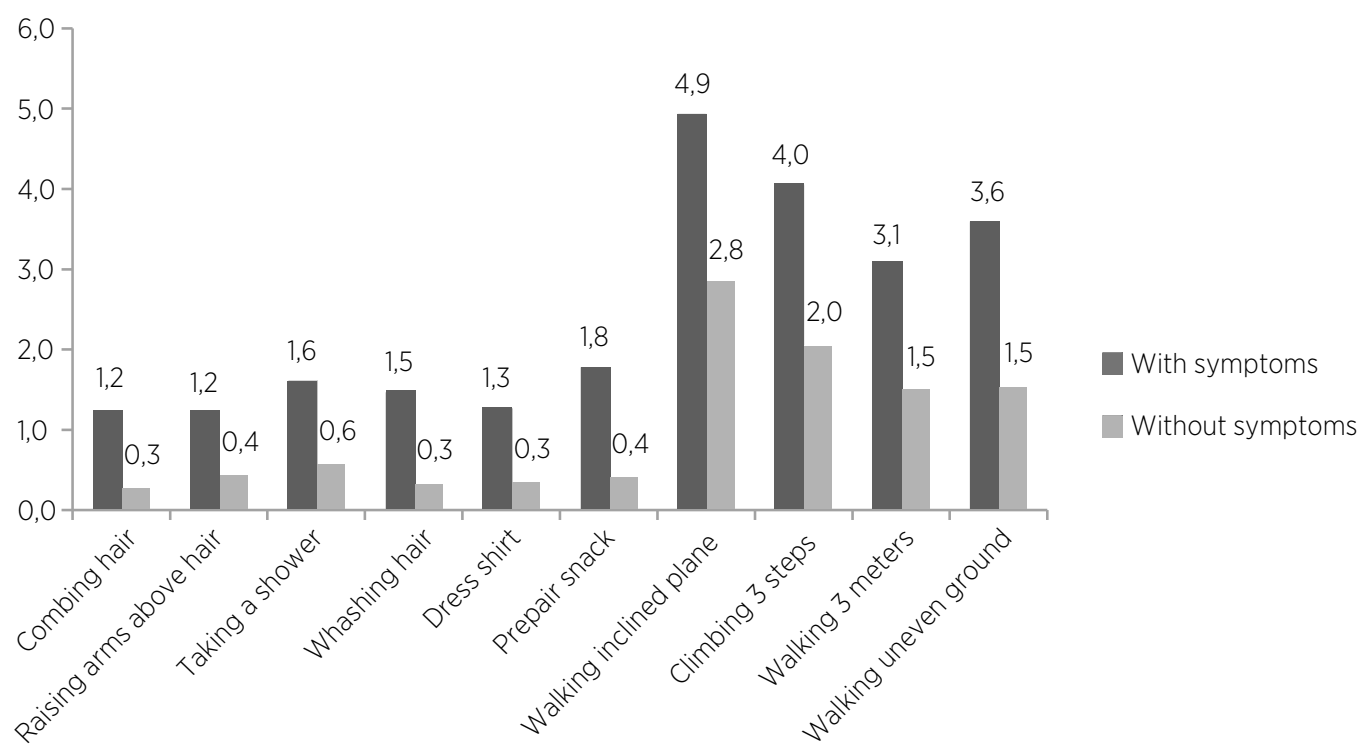

Figure 2. Limitations in activities of daily living imposed by fatigue according to the PSFDQ in the presence and absence of depressive symptoms 


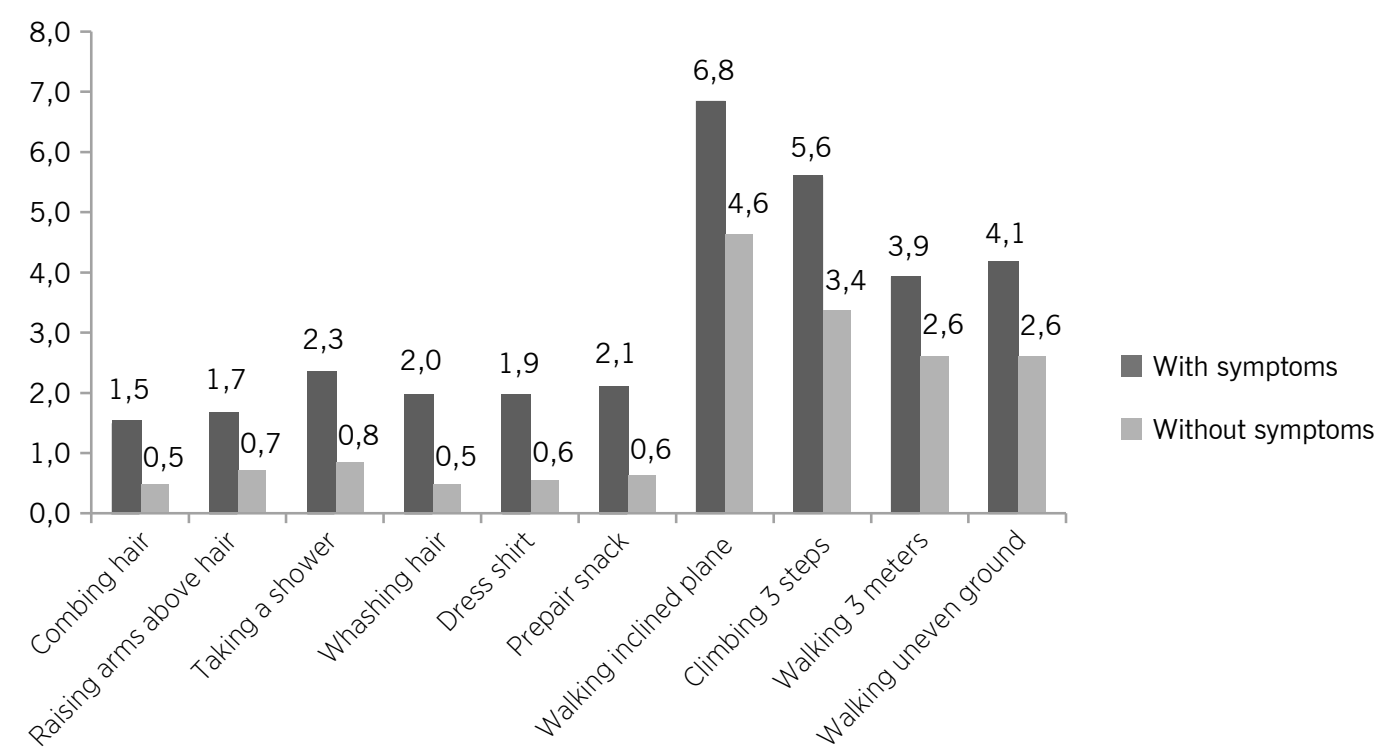

Figure 3. Changes in daily living activities before and after COPD according to the PSFDQ in the presence and absence of depressive symptoms

According to the logistic regression analysis, not having a partner $(\mathrm{OR}=2.58, \mathrm{p}=0.004)$, using more than one bronchodilator $(\mathrm{OR}=2.82, \mathrm{p}=0.002)$, presenting dyslipidemias $(\mathrm{OR}=2.74, \mathrm{p}=0.0012)$, heart diseases $(\mathrm{OR}=2.82, \mathrm{p}=0.02)$, and expectoration $(\mathrm{OR}=2.44, \mathrm{p}=0.014)$ increased the odds of developing depressive symptoms in patients with COPD and ADL impairment (Table 2).

Table 2. Logistic regression of the individuals who participated in the study

\begin{tabular}{lrrr}
$\quad$ Variables & OR & Cl 95\% & p-value \\
Marital Status & & & \\
With partner & 1 & - & 0.004 \\
Without partner & 2.58 & $1.36-4.9$ & \\
Expectoration & & & \\
Yes & 2.44 & $1.2-4.95$ & 0.014 \\
No & 1 & - & \\
Bronchodilator & & & \\
Yes & 2.82 & $1.47-5.38$ & 0.002 \\
No & 1 & - & \\
Heart Disease & & & \\
Yes & 2.82 & $1.18-6.74$ & 0.02 \\
No & 1 & - & \\
Dyslipidemia & & & \\
Yes & 2.74 & $1.24-6.07$ & 0.012 \\
No & 1 & - & \\
\hline
\end{tabular}

OR: Odds ratio; Cl: confidence interval. Logistic regression by Backward Lr method.

\section{DISCUSSION}

This study identified a $38.6 \%$ prevalence of depressive symptoms in patients with COPD and changes in all areas of the PFSDQ-M questionnaire in these patients. Factors which increased odds for developing depressive symptoms for ADL impairment in COPD patients in our study were: not having a partner, presenting expectoration, dyslipidemia and heart disease, and using more than one bronchodilator.

The presence of depressive symptoms can be defined as the existence of depressed mood, and loss of interest or pleasure in activities which can cause damage in social, occupational and functional actions of an individual ${ }^{21}$. Depressive symptoms among patients with COPD are considered the main psychiatric comorbidity of this group, representing the systemic and extra pulmonary disease stage ${ }^{3,21-23}$ capable of determining a decrease in functionality, development of activities ${ }^{24,25}$, and quality of life ${ }^{5}$.

The occurrence of depressive symptoms in patients with COPD may be due to chronic disease, decreased physical capacity and occupational performance, anticipation of retirement, functional limitations related to the execution of daily activities, and low self-esteem ${ }^{26}$.

Our study showed a $38.6 \%$ prevalence of depressive symptoms, a little higher than that found in the study by Zhang et al. ${ }^{16}$, which identified a $24.6 \%$ prevalence of depressive symptoms in patients with COPD compared to the control group, and also found that patients with COPD were 2.8 times more likely to have depressive symptoms. Oliveira and Gonçalves ${ }^{21}$ showed that depressive symptoms compromise $10-60 \%$ of these individuals, and factors such as smoking, social isolation, use of medications for COPD treatment (corticosteroids, bronchodilators) can cause psychiatric symptoms or intensify problems such as depressive mood, mania, psychosis, delirium, or behavioral changes, which is similar to the findings in our study. 
Comorbidities in patients with COPD are a common feature when dealing with an inflammatory disease ${ }^{23,27,28}$. Depressive symptoms in patients with COPD are an important and prevalent comorbidity associated with mortality ${ }^{7,29}$, thereby worsening the health condition and functional status of the individual ${ }^{30}$. According to our results, patients with depressive symptoms had more comorbidities, which can worsen the clinical course of COPD due to their inflammatory nature ${ }^{28}$.

Compromised ADL were high in the group with depressive symptoms, indicating worse performance for all related activities, showing greater restriction in the execution of activities and loss of functional autonomy. ADL are related to actions which are performed daily by a person and correspond to an individual's ability to dress, feed, bathe, groom, and move ${ }^{31}$, and when involved with depressive symptoms can result in a patient's loss of functionality 11-13,32,33, autonomy and independence ${ }^{21}$.

Altenburg ${ }^{11}$ and Mauoa ${ }^{32}$ reported difficulties for patients with anxiety and depression in performing daily physical activities ${ }^{11}$, and they also found that the presence of comorbidities and depression are associated with significant impairment in the quality of life of these individuals ${ }^{32}$.

Bendixen et al. ${ }^{12}$ also found inefficiency in performing tasks involving patients with COPD, and about $90 \%$ reported tiredness and more effort in order to perform such activities; this is similar to our study, although the patients with COPD had no depressive symptoms. Functional limitations in activities of daily living may not only be perceived by patients due to the severity of lung disease, because their level of physical activity, which is required for ADL, is hindered by dyspnea ${ }^{3,34}$.

Reduced exercise capacity is a common complaint among patients with COPD and this restriction in performing activities of daily living can be explained by extra-pulmonary manifestations of the disease and musculoskeletal dysfunction. The latter can be attributed to the presence of the systemic inflammatory process of the disease, chronic inactivity, malnutrition, smoking, hypoxemia, and use of medication for treatment, which favor the individual's poor physical conditioning ${ }^{35}$.

Although all areas of PFSDQ are compromised, it is observed that the activities related to patient mobility (walking on an inclined plane, climbing 3 steps, walking on uneven ground and walking 3 meters) were proven to be more limited, requiring greater effort in their lower limbs. This fact may be related to patients with COPD having peripheral muscle dysfunction and reduced ability to exercise, which is associated with changes in strength and musculoskeletal structure (reduced muscle strength and atrophy of muscle fibers), as well as psychological repercussions ${ }^{36}$.

The main limitation of this study was that we did not perform spirometry evaluation, but, in order to compensate this, we report the last spirometry achieved in the medical records.

The presence of depressive symptoms was relatively high among patients with COPD, and ADL were compromised in this group of patients. A lack of screening to detect these symptoms may contribute to the maintenance or worsening of clinical symptoms of the disease and increase the number of comorbidities, since COPD is an inflammatory systemic disease with extra-pulmonary manifestation.

\section{IMPLICATIONS FOR THE PRACTICE OF PHYSICAL THERAPY}

Suffering from ADL may result in loss of functional autonomy and worsening of depression symptoms, making it necessary to investigate and treat them. Lastly, we suggest that the assessment of ADL must be part of clinical practice so that changes in this area can be detected and treated at an early stage.

\section{REFERENCES}

1. Barnes PJ, Celli BR. Systemic manifestations and comorbidities of COPD. Eur Respir J. 2009;33:1165-85. doi: 10.1183/09031936.00128008

2. Weldam SWM, Lammers JWJ, Decates RL, Schuurmans MJ. The daily activities and quality of health of life in patients with chronic obstructive pulmonary disease: psychological determinants: a cross sectional study. Health Qual Life Outcomes. 2013;11:190. doi: 10.1186/1477-7525-11-190

3. Schane RE, Walter LC, Dinno A, Covinsky KE, Woodruff PG. Prevalence and risk factors for depressive symptoms in persons with chronic obstructive pulmonary disease. J Gen Int Med. 2008;23(11):1757-62. doi: 10.1007/s11606-008-0749-z

4. Vogele C, Von Leupoldt A. Mental disorders in chronic obstructive pulmonary disease (COPD). Respir Med. 2008;102(5):764-73. doi: 10.1016/j.rmed.2007.12.006

5. Kühl K, Schürmann W, Rief W. Mental disorders and quality of life in patients with COPD and their spouses. Int J Chron Obstruct Pulmon Dis [Internet]. 2008 [cited 2020 June 17];3(4):727-36. Available from: www.ncbi.nlm.nih.gov/ pmc/articles/PMC2650604/pdf/COPD-3-727.pdf

6. Stone RA, Lowe D, Potter JM, Buckingham RJ, Roberts CM, Pursey NJ. Managing patients with COPD exacerbation: does age matter? Age Ageing. 2012;41(4), 461-68. doi: 10.1093/aging/afs039 
7. Voogd JN, Wempe JB, Koëter GH, Postema K, van Sonderen E, Ranchor AV. Depressive symptoms as predictors of mortality in patients with COPD. Chest. 2009;135:619-25. doi: 10.1378/chest.08-0078

8. Pooler A, Beech R. Examining the relationship between anxiety and depression and exacerbations of COPD which result in hospital admission: a systematic review. Int J Chron Obstruct Pulmon Dis. 2014;9:315-30. doi: 10.2147/COPD.S53255

9. Li LSK, Caughey GE, Johnston KN. The association between co-morbidities and physical performance in people with chronic obstructive pulmonary disease: A systematic review. Chron Respir Dis. 2014;11(1):3-13. doi: 10.1177/1479972313516879

10. Di Marco F, Terraneo S, Roggi MA, Repossi AC, Pellegrino GM, Veronelli A. Physical activity impairment in depressed COPD subjects. Respir Care. 2014;59(5):726-34. doi: 10.4187/ respcare.02848

11. Altenburg WA, Bossenbroek L, De Greef MH, Kerstjens HA, Ten Hacken NH, Wempe JB. Functional and psychological variables affect daily physical activity in patients with COPD: A structural equation model. Respir Med. 2013;107(11):1740-7. doi: 10.1016/j.rmed.2013.06.002

12. Bendixen HJ, Wæhrens E, Wilcke JT, Sørensen LV. Selfreported quality of $A D L$ task performance among patients with COPD exacerbations. Scand J Occup Ther. 2014;21(4):313-20. doi: 10.3109/11038128.2014.899621

13. Chatila WM, Thomashow BM, Minai OA, Criner GJ, Faça BJ. Comorbidities in chronic obstructive pulmonary disease. Proc Am Thorac Soc. 2008:5:549-55. doi: 10.1513/pats.200709-148ET

14. Global Initiative for Chronic Obstructive Lung Disease. Global Strategy for the Diagnosis, Management and Prevention of COPD. Fontana; 2014

15. Hornikx M, Van Remoortel H, Demeyer H, Camillo CAM, Decramer $M$, Janssens W, Troosters T. The influence of comorbidities on outcomes of pulmonary rehabilitation programs in patients with COPD: a systematic review. Biomed Res Int. 2013;26:8. doi: 10.1155/2013/146148

16. Zhang MW, Ho RC, Cheung MW, Fu E, Mak A. Prevalence of depressive symptoms in patients with chronic obstructive pulmonary disease: a systematic review, meta-analysis and meta-regression. Gen Hosp Psychiatry. 2011;33(3):217-23. doi: 10.1016/j.genhosppsych.2011.03.009

17. Carvalho NS, Ribeiro RP, Ribeiro M, Nunes MPT, Cukier A, Stelmach R. Asma e doença pulmonar obstrutiva crônica: uma comparação entre variáveis de ansiedade e depressão. J Bras Pneumol. 2007;33(1):1-6. doi: 10.1590/S1806-37132007000100004

18. Kovelis D, Segretti NO, Probst VS, Lareau SC, Brunetto AF, Pitta F. Validação do Modified Pulmorary Status and Dyspnea Questionnaire e da escala do Medical Research Council para uso em pacientes com doença pulmonar obstrutiva crônica no Brasil. J Bras Pneumol. 2008;34(12):1008-18. doi: 10.1590/S1806-37132008001200005

19. Gomes-Oliveira MH, Gorenstein C, Lotufo Neto F, Andrade LH, Wang YP. $V$ alidation of the Brazilian Portuguese version of the Beck Depression Inventory-II in a community sample. Rev Bras Psiq. 2012;34:389-94. doi: 10.1016/j.rbp.2012.03.005

20. Quilty LC, Zhang KA, Bagby RM. The latent symptom structure of the Beck Depression Inventory-II in outpatients with major depression. Psychol Assess. 2010;22(3):603-8. doi: 10.1037/a0019698

21. Oliveira MTS, Gonçalves M. Doença pulmonar obstrutiva crônica e sintomas psiquiátricos: uma revisão de literatura. Psych On-line Br [Internet]. 2015 [cited 2020 June 17];20(3). Available from: www.polbr.med.br/ano15/prat0315.php

22. González-Gutiérrez MV, Velázquez JG, García CM, Maldonado FC, Jiménez FJG, Vargas FG. Predictive Model for Anxiety and Depression in Spanish Patients with Stable Chronic Obstructive Pulmonary Disease. Arch Bronconeumol. 2015;52(3):151-7. doi: 10.1016/j.arbres.2015.09.003

23. Dal Negro RW, Bonadiman L, Turco L. Prevalence of different comorbidities in patients with COPD by gender and GOLD stage. Multidiscip Respir Med. 2015;10(1):24. doi: 10.1186/ s40248-015-0023-2

24. Sievi NA, Senn O, Brack T, Brutsche MH, Frey M, Irani S. Impact of comorbidities on physical activity in COPD. Respirology. 2015;20:413-18. doi: 10.1111/resp.12456

25. Laurin C, Moullec G, Bacon SL, Lavoie KL. Impact of Anxiety and Depression on Chronic Obstructive Pulmonary Disease Exacerbation Risk. Am J Respir Crit Care Med. 2012;185(9):918-23. doi: 10.1164/rccm.201105-0939PP

26. Heckler M, Weingartner R, Moreira JS, Prezzi S, Tombini N. Prevalência de depressão em pacientes com doença pulmonar obstrutiva crônica. J Pneumol. 1997;23(5):231-6.

27. Wouters EFM, Celis MPM, Breyer MK, Rutten EPA, GraatVerboom L, Spruit MA. Co-morbid manifestations in COPD. Respir Med: COPD Update. 2007:3:135-51. doi: 10.1016/j. rmedu.2007.08.003

28. van Manen JG, Bindels PJE, IJzermansa CJ, van der Zee JS, Bottema BJAM, Schadé E. Prevalence of comorbidity in patients with a chronic airway obstruction and controls over the age of 40. J Clin Epidemiol. 2001;54:287-93. doi: 10.1016/ S0895-4356(01)00346-8

29. Fan VS, Ramsey SD, Giardino ND, Make BJ, Emery CF, Diaz PT. Sex, Depression, and Risk of Hospitalization and Mortality in Chronic Obstructive Pulmonary Disease. Arch Int Med. 2007;167(21):2345-53. doi: 10.1001/archinte.167.21.2345

30. Ng TP, Niti M, Fones C, Yap KB, Tan W-C. Co-morbid association of depression and COPD: A population-based study. Respir Med. 2009;103(6):895-901. doi: 10.1016/ j.rmed.2008.12.010

31. Velloso M, Jardim JR. Functionality of patients with chronic obstructive pulmonary disease: energy conservation techniques. J Brasil Pneumol. 2006;32(6):580-6. doi: 10.1590/ S1806-37132006000600017

32. Maoua M, El Maalel O, Abdelghani A, Boughattas W, Kalboussi $\mathrm{H}$, Chatti S. Impact of COPD on quality of life and mental health among one hundred Tunisian patients. Rev Pneumol Clin. 2014;70(4):195-202. doi: 10.1016/j.pneumo.2013.11.009

33. Costa GMO, Santos RCAS, Marinho PEM. Atividade de vida diária e sintomas depressivos em pacientes com doença pulmonar obstrutiva crônica. ConScientiae Saúde. 2017;16(4):402-8. doi: 10.5585/ConsSaude.v16n4.7662

34. Karloh M, Araujo CLP, Gulart AA, Reis CM, Steidle LJM, Mayer AF. The Glittre-ADL test reflects functional performance measured by physical activities of daily living in patients 
with chronic obstructive pulmonary disease. Braz J Phys Ther. 2016;20(3):223-30. doi: 10.1590/bjpt-rbf.2014.0155

35. Kim HC, Mofarrahi M, Hussain SN. Skeletal muscle dysfunction in patients with chronic obstructive pulmonary disease. Int J Chron Obstruct Pulmon Dis [Internet]. 2008 [cited 2020
June 17];3(4):637-58. Available from: www.ncbi.nlm.nih.gov/pmc/ articles/PMC2650609/pdf/COPD-3-637.pdf

36. Mador MJ, Boskanat K. Steletal muscle dysfunction in chronic obstructive pulmonary disease. Respir Res. 2001;2(4):216-24. doi: $10.1186 /$ rr60 